\title{
Sik Domontios
}

\section{Adalékok az eldologıasodás fenomenológı́aához}

Az eldologiasítás problematikája sajátos helyet foglal el a kritikai elméletek történetében. Marxnál ez hivatott a leginkább kézzelfogható módon kifejezni a kapitalista termelési viszonyok társadalmi relációkra gyakorolt pusztító hatását. Ebben az értelemben az eldologiasodás tézise a társadalomkritikai hagyomány olyan paradigmatikus diagnózisának tekinthető, ami viszonyítási pontként szolgál a marxi elgondolásokat szorosabban és kevésbé szorosan követők számára egyaránt. E fogalom talán minden egyéb kritikai kategóriánál plasztikusabban fejezi ki, hogy miként képzelhető el a személyközi viszonyok torzulásának határállapota: amennyiben a cselekvők kognitív és morális sajátosságokkal rendelkező szubjektum helyett egyszerü tárgyként tekintenek egymásra (és ezzel összefüggésben önmagukra is), úgy hétköznapi gyakorlatukban fejeznek ki egy - szó szerint - „elembertelenedett” társadalmi konstellációt. Ebben az értelemben a dehumanizálás tapasztalatát eredményezve, az eldologiasodás a társadalmi szenvedések szempontjából is kitüntetett jelentőségü (Wilkinson 2005). Egy olyan tapasztalatra utal, ami nem csupán kellemetlen átélője számára, hanem azáltal, hogy megfosztja emberi méltóságától, a szenvedés egzisztenciális határállapotával jár. E tapasztalat abban az értelemben par excellence társadalminak tekinthetö, hogy túlmutat a testi fájdalom és lelki gyötrelmek tartományán, amennyiben a társakhoz való viszony torzulásából fakad.

Fontos hangsúlyozni, hogy a szenvedés problematikája nem csupán járulékos következménye az eldologiasodásnak, hanem bizonyos értelemben annak lényegi eleme. Objektum és szubjektum közötti különbség ugyanis a szenvedésre adott reakcióban fejeződik ki: míg egy tárgy amortizációja legfeljebb gazdaságossági kérdés és ennyiben nem vonja magával szükségszerüen az állagmegőrzés imperatívuszát, addig egy személy szenvedése húsba vágó morális tapasztalat, ami elől csak a másik dologként való kezelésével lehet kitérni (Lévinas 1988). Ebben az általános értelemben az eldologiasodás elsősorban „szenvedni hagyásként” fogható fel, vagyis a társulások dinamikájának a szenvedések tapasztalatától való eloldódásaként. Ez oly módon képzelhető el, hogy a kifejezésre juttatott szenvedést a társak semmibe veszik, és nem hagyják érvényesülni a közös ügyek formálódásának folyamatában. 
Ez egyaránt jelentheti azt, hogy a szenvedés csökkentésére tett kísérleteket direkt módon akadályozzák, és azt is, hogy passzívan viszonyulva hozzá, elmulasztják a segítségnyújtást.

A kritikai elméletek szempontjából kitüntetett jelentőségének tudható be, hogy az eldologiasodás mind a mai napig egyfajta standard normatív bázisként szolgál: egy olyan mérceként, melyhez újabb és újabb kordiagnózisok egyaránt hozzámérik magukat. Ugyanakkor ez korántsem jelenti azt, hogy az eldologiasodás kizárólag az eredeti marxi formájában élne tovább: a kortárs kritikai elméletek arra tesznek kísérletet, hogy a kapitalista termelési viszonyokra való hivatkozás helyett alternatív oksági keretbe ágyazzák a szubjektum objektummá transzformálásának folyamatát. Ebben az értelemben az eldologiasodáselméletek történetében hasonló típusú társadalmi szenvedések különböző integrációs torzulásokkal történő magyarázatai jelennek meg. Az alábbi tanulmány első szakaszában ezeket tekintem át röviden: egyaránt kitérek Marx (eldologiasítás mint kapitalista termelési viszonyok között áruvá vált bérmunkás, vagyis a munka világának patológiája), Lukács (eldologiasítás mint totális elidegenedés, vagyis az öntudat és a másik percepciójának patológiája), Habermas (eldologiasodás mint rendszergyarmatosítás, vagyis a funkcionalista ész benyomulása a szocializáció, kulturális újratermelés, társadalmi integráció területére) és Honneth (eldologiasodás mint elismerésfeledés, vagyis az intimitás, szolidaritás vagy jog patológiája) diagnózisaira.

E különböző magyarázatok az eldologiasodás értelmezésének sajátos ívét vázolják fel, melyben a kezdetben domináns gazdasági okok (proletár osztályhelyzet és kapcsolódó osztálytudat) fokozatosan átadják a helyüket általánosabb megközelítéseknek (rendszerek gyarmatosítása, elismerés hiánya). Ezekre úgy tekinthetünk, mint különböző történeti konstellációkban született ideáltipikus leírásokra, melyeknek a modernizáció későbbi szakaszaiban csökkenhet ugyan a jelentőségük, azonban teljesen nem veszik el. Ilyenformán amellett érvelhetünk, hogy fokozatosan egymásra rétegződnek, az eldologiasodás egyre komplexebb tapasztalati terét hozva létre (Sik 2015). Ennek bemutatása céljából a második szakaszban egy esettanulmány segítségével azt igyekszem leírni, hogy miként állnak össze az eldologiasodás különböző integrációs terekben formálódó komponensei egy koherens egésszé a késő modern élettörténetekben.

\section{Az eldologiasodás kritikai elméletei}

Marx eldologiasodásfogalmának megértésére - ahogy azt tanulmányában Márkus György (1982) részletesen bemutatja - a materiális újratermelés általános és a különböző formációkra jellemző specifikus funkcionális komponenseinek számbavétele kínál lehetőséget. Minden gazdasági rendszernek valamilyen választ kell adnia arra a kérdésre, hogy milyen arányok szerint osztja el a termelési feladatokat, eszközöket, erőforrásokat és fogyasztási lehetőségeket. A különböző formációk ebben az értelemben ugyanazon szükségletekre adott alternatív megoldásoknak tekinthetők: esetükben más-más alárendelési viszonyokat kijelölő integrációs keretek között végzett tevékenységek hivatottak a materiális újratermelés funkcionális szükségleteinek kielégítésére. Ebben az értelemben a materiális újratermelés adott típusa egyaránt meghatározza az ember és természet (technikai eszközök), valamint az ember és ember (társadalmi hierarchiák) közti relációt. E gazdasági formációk amellett, hogy keretezik a materiális újratermelés folyamatát, egyúttal kifejezik annak céljait és határait is. Az, hogy adott történeti konstellációban milyen személyközi viszonyok között, milyen 
technikai eszközökkel történik a termékek elöállítása és cseréje, elválaszthatatlan attól, hogy milyen tágabb célrendszerhez igazodnak ezek a folyamatok. Az eldologiasodás ebben a fogalmi térben értelmezhető a kapitalista termelési viszonyok sajátos célrendszeréből fakadó következményként (Márkus 1982: 149-150).

A kapitalizmust megelőző formációk egyik központi jellemzője, hogy a termelési és cserefolyamatokat lokálisan, egymástól független egységek végzik, aminek következtében a megtermelt javak mozgása korlátozott. A helyhez kötöttség mellett legalább olyan fontos az is, hogy a gazdasági tranzakciók olyan társadalmi viszonyok hálójába ágyazódnak be, melyek hozzájuk képest dominánsak. Ez azt jelenti, hogy a fennálló törzsi, politikai, vallási vagy éppen személyes függőségi rendszerekben elsősorban a status quo újratermelésének eszközeként tekintenek a termelési és cserefolyamatokra, anélkül hogy hatékonyságának kitüntetett jelentőséget tulajdonítanának. Ennek megfelelően a termelés technikai feltételeivel kapcsolatban sem a fejlödés, hanem sokkal inkább a hagyományok követése az elsődleges elvárás, amennyiben ily módon a munkafolyamatok hétköznapiságában kerülnek megerősítésre a fennálló viszonyok. Ez fejeződik ki a termeléshez kapcsolódó kollektív rítusokban és a normatívan szabályozott, leszármazási alapú, kötött munkamegosztási viszonyokban egyaránt. Összességében a prekapitalista keretek között a helyhez kötöttség az expanziót, a tradicionális rend dominanciája pedig a technikai fejlődést akadályozza, egyfajta kiküszöbölhetetlen belső korlátként (Márkus 1982: 151).

A kapitalizmus ezt a konstellációt változtatja meg: ahogy a termelési és cserefolyamatok egyetlen szempontjává a tőke - piaci versenyből fakadóan - szüntelen felhalmozása válik, úgy az ember és természet, valamint az ember és ember közti viszonyt meghatározó technikai és társadalmi korlátok egyaránt lebomlanak. A természet és az ember egyaránt csereértékére redukálódik: azáltal és annyiban létezik, ahogy és amennyiben a termelési és piaci folyamatok része (Marx 1955: 76). Bár a prekapitalista társadalmakban a fennálló kereteket konzerváló tradíció a változás akadálya volt, azonban egyúttal - egyenlőtlen mértékben ugyan, de - biztosította a természethez és az emberhez való viszonyulás csereértéktől független lehetőségét. Ezzel szemben a tőkeakkumuláció kényszere által hajtott kapitalizmusban a szüntelen változás válik szükségszerűvé, aminek következtében a természet a szükségletkielégítéshez felhasznált erőforrássá, az ember pedig a termelési folyamatot müködtető munkaerővé alakul át. A partikuláris sajátosságaitól ily módon megfosztott természetre és emberre támaszkodó kapitalizmust mind a lokális kereteken, mind pedig a tradíciók szabta korlátokon való átlépés, vagyis folyamatos expanzió jellemzi. Minthogy ez a dinamika egyaránt figyelmen kívül hagyja a természet és az ember érdekeit, ezért öncélúnak tekinthető. A létező korlátok lebontása ugyanakkor korántsem ellentmondásmentes: a piaci viszonyok anomáliáival és paradoxonjaival összefüggő válságok szakítják meg. Ezek azonban nem képesek magát a tőkefelhalmozás logikáját kérdésessé tenni, lecsengésüket követően ismét az értéktöbblet szempontjai válnak kizárólagossá.

Összességében a profitabilitás és a hatékonyság szempontjainak kizárólagossá válásával a „második természetté” váló piac formájában olyan kényszerstruktúra jön létre, melynek hatásától egyre kevésbé lehetséges függetlenedni (Marx 1955: 77-78). A termelési és csereviszonyok tradicionális kereteinek lebomlásával a technikai és társadalmi viszonyok egyaránt az „áru” absztrakt formáját öltik, melyhez való viszonyulást a - keresleti és kínálati görbék által meghatározott - csereérték határozza meg. Ebben a konstellációban az értéktöbblet elöállításának szempontjai totálissá válnak, aminek következtében a piac törvényei „termé- 
szeti törvényekké” lesznek. Ez mindennél világosabban fejeződik ki abban, hogy a materiális újratermelés technikai és társadalmi elemei összeolvadnak egymással. A munkafolyamaton belül megszünik az emberi munka által hozzáadott érték megkülönböztetett státusa: ahogy a termelés kizárólagos logikájává a profitabilitás lesz, a munkás beleolvad a technikai környezetbe, melyet korlátok nélkül a hatékonyság szolgálatába lehet állítani. A tőkefelhalmozás totálissá váló piaci logikáját ilyenformán a munkafolyamat technikai formát öltő kényszerei közvetítik a munkások számára, természeti szükségszerüségként tüntetve fel az elidegenítő termelési viszonyokat. Ahogy a tőke kizárólagos felügyeletet gyakorol a munkafolyamatok felett, a technikai szempontok pedig a munkavégzés felett, úgy válik „dologgá” a munkás (Márkus 1982: 152).

A társadalmi interakciók felügyeletétől eloldódott termelési folyamatokból fakadó eldologiasodás további következményei a társadalmi kapcsolódások antagonisztikus tendenciái, melyek eredményeként a természethez, másikhoz és önmagához való viszony egyaránt elidegenedetté válik. Ebben az értelemben eldologiasodás és elidegenedés kölcsönösen feltételezik egymást: egyrészt azáltal, hogy a kapitalizmusban az értéktöbblet realizálásának szempontjai kizárólagossá válnak, a szubjektumok elveszítik ágenciájukat, vagyis kiszorulnak a saját tevékenységük eszközei és céljai feletti kontroll gyakorlásából. Másrészt azáltal, hogy természetessé, magától értetődővé válik a személyközi viszonyok olyan rendje, ami alá van rendelve a termelés technikai követelményeinek, a piac totális logikája megkérdőjelezhetetlenné lesz. A fogalmak e kapcsolatának feltárása elsősorban amiatt fontos, mert csakis ennek fényében értelmezhetők a - fennálló patologikus viszonyok meghaladása által motivált - kritikai következmények. Minthogy eldologiasodás és elidegenedés együttesen egy különösen ellenálló rendszerré áll össze, ezért meghaladásuk is csak együttesen képzelhető el, az alapjukul szolgáló termelési viszonyok átalakításával (Márkus 1982: 153).

Bizonyos értelemben Lukács (1971) is e belátásból indul ki Marx továbbgondolásakor: a Történelem és osztálytudatban arra tesz kísérletet, hogy az elidegenedés felől tágítsa ki az eldologiasodásra vonatkozó belátásokat. Ezt a döntést - ahogy azt írásában Arató András részletesen elemzi - annak a nehézségnek a felismerése eredményezi, hogy az eldologiasodás nem korlátozódik a gazdasági rendszerre, hanem a kapitalista társadalmak egészét érinti. Minthogy az elidegenedéssel kiegészült eldologiasodás áthatja a hétköznapi élet praxisait, így ezek meghaladása sem képzelhető el egyfajta voluntarista modellben, pusztán a proletariátus szándékolt erőfeszítéseként - hiszen ezek lényegi szintje el van zárva az akaratlagosan befolyásolható döntésektől (Lukács 1971: 333). Erre csakis akkor nyílik lehetőség, ha figyelembe vesszük a kapitalizmus cselekvők valóságértelmezésére gyakorolt hatását és ezen az intencionális szinten azonosítjuk az eldologiasodás következményeit, továbbá ezekből bontjuk ki a változás lehetőségét. Ezen a ponton egészíti ki Lukács Marx téziseit Weber racionalizálódásra vonatkozó elemzéseivel (Arató 1972: 33).

A kapitalista termelési viszonyok központi sajátosságának a munka - árufetisizmus következtében lezajló - absztrakttá válásának folyamatát tekinti. Ez egyrészt abban fejeződik ki, hogy a munka a piacon értékesített áruvá válik, másrészt abban, hogy a gyárakban egy mechanikusan beszükített repetitív viselkedésmintázatra redukálódik (Lukács 1971: 320). E kettős értelemben kapcsolható össze a marxi absztrakttá váló munka fogalma a weberi formális racionalitás tézisével. A modern tudományokban, művészetekben és életformában egyaránt felbukkanó racionalitás abban az értelemben formális, hogy kizárólag 
a kvantifikálás és kalkuláció logikáján alapul, miközben figyelmen kívül hagy minden szubsztantív értéket. E kritériumoknak leginkább a repetitív, standardizált, elemekre osztott cselekvésformák felelnek meg, így a modernizálódással párhuzamosan ezek elterjedése figyelhető meg. E folyamatok egyaránt megjelennek a hétköznapi cselekvéshelyzetekben és ideáltipikus formában a munka világában. A gyárakban az eloóllított termék és a munkát végzők egyaránt fragmentálódnak: individuális sajátosságaik és integritásuk teljes mértékben felszámolásra kerülnek, és - ahogy azt legnyíltabb formában a taylorizmus kifejezi maguk is alkatrészeket gyártó, részfeladatokra specializálódott automatává válnak. Ebben a helyzetben a munkás ahelyett, hogy aktív alakítója lenne, passzív szemlélőjévé válik a munkafolyamatnak, amivel szorosan összefügg az is, hogy a társakkal végzett közös cselekvés kezdeményezésére is képtelenné válik. A formális racionalitás a társadalmi integráció szempontjából az atomizált egyének szerződések révén történő koordinációját eredményezi. Így összességében egyszerre vezet a munkafolyamat, a szubjektum és a társadalmi kapcsolatok fragmentálódásához (Arató 1972: 34).

A formális racionalitás weberi elméletének hozzákapcsolása az eldologiasítás problematikájához annak további dimenzióit teszi megragadhatóvá. Ahogy azt Weber bemutatja, a termelés és kereskedelem racionalizálódása nem képzelhető el egyrészt a jog, az adminisztratív rendszer és még inkább a hétköznapi cselekvések hasonló irányú átalakulása nélkül. Ebben az értelemben az eldologiasodás sem korlátozódik kizárólag a gazdaság és a munka világára: a jogra, a politikára és általában a társas cselekvésekre egyre inkább igaz lesz az, hogy részkérdésekre fókuszáló technikai megoldásokat kínálnak. Ahogy kizárólagos viszonyítási pontként szolgálnak, ugyanezek fokozatosan olyan kényszerstruktúrává is válnak, ami fölött az egyes cselekvők nem képesek kontrollt gyakorolni, melynek csak alávetni tudják magukat: a résztvevő cselekvőperspektíva fokozatosan átadja helyét egy „objektivitásra” törekvő, szenvtelen, megfigyelöi nézőpontnak. Ebben az értelemben válik Lukács szerint a munkás eredetileg partikuláris elidegenedése a kapitalizmus osztályhelyzettől független, általános tapasztalatává (Lukács 1971: 343). ${ }^{1} \mathrm{Ez}$ az „értelemvesztés” kifejeződik egyfelől a cselekvők szubjektív tudatában: amennyiben a világ kizárólag fragmentumként lesz hozzáférhető, sem az értékeknek, sem pedig a technikáknak nem adható a hatékonyságon kívül semmilyen értelem. Másfelől a modern pozitivista tudományokban és filozófiában, melyek részterületekre specializálódva, bürokratikus keretek között müködve lemondanak arról, hogy a természetet és a társadalmat átfogó perspektívában, nem csupán az adott, hanem a lehetséges felöl értsék meg (Arató 1972: 35-37).

Minthogy az eldologiasodást Lukács nem tekinti osztályspecifikus jelenségnek, különösen nehézzé válik számára a meghaladás lehetőségére vonatkozó kérdés megválaszolása. Annak ellenére, hogy az elidegenedés a tőkés és proletár számára egyformán meghatározza a tudatot, az annak okaként szolgáló árufetisizmushoz füződő viszonyuk különbségéből fakadóan mégis eltérő formát ölt. Míg a tőkés számára - lehetőségek tárházaként - a kapitalizmus természetes, örökkévaló konstellációnak tűnik, addig a proletár számára - korlátok és szenvedések forrásaként - meghaladásra motiváló, és ennyiben meghaladhatóként elképzelt,

1 Ebből a szempontból külön érdekes, hogy nem is a kétkezi munkásra, hanem a hivatalnokra tekint úgy Lukács, mint a leginkább elidegenedett társadalmi csoportra: ő ugyanis a jogszabályok feltétel nélküli alkalmazójaként a morális autonómiájáról mond le, és ilyenformán saját etikai dimenzióját kénytelen eldologiasítani (Arató 1972: 36). 
vagyis történeti állapotként. Ebből fakadóan a proletariátus potenciálisan annak ellenére is forradalmi osztálynak tekinthető, hogy tényleges osztálytudatát az elidegenedés dominálja, és ezért nem tud „önmagáért való osztályként” megszerveződni (Arató 1972: 57). ${ }^{2}$

Az eldologiasodás tudat szintjére történő kiterjesztése az a priori ítéletek olyan formájára utal, ami a természeti, társadalmi és szubjektív jelenségek tartalmilag kiüresedett, absztrakt dologként történő megragadását eredményezi. Habermas ezen a ponton kapcsolja hozzá saját elemzéseit az eldologiasodás kérdéséhez: ahelyett, hogy a cselekvők szubjektív értelmi tartalmainak szintjén lokalizálná azt, a kölcsönös megértés kommunikatív folyamataiban azonosítja megjelenésüket. A kritikai elmélet nyelvi fordulatából fakadó következmények levonása az eldologiasodás tézisére annak átfogalmazását eredményezi. Végső okai a kapitalizmus helyett a szimbolikusan általánosított kommunikációs médiumok által integrált alrendszerek lesznek. Ezek abban az értelemben egyfajta paradox fejlődési pályát járnak be, hogy egyfelöl a nyelvi interakciókban formálódó életvilág racionalizálódására vannak ráutalva, ugyanakkor a kommunikáció mediatizált pályára történő terelésével éppen ezt az alapot ássák alá. A médiumok által koordinált alrendszerekben az érvényességi igények kritikáján és igazolásán alapuló kölcsönös megértésre törekvő valóságkonstrukció helyett funkcionális szempontokhoz igazodó szemantikák által szabványosított értelmezési horizontok jelennek meg. Ezek egyaránt kitakarják a müködésük szempontjából irreleváns információkat és a cselekvők egyedi sajátosságait (Habermas 1986: 187).

Ebből a perspektívából tekintve az eldologiasodásra, a kapitalizmus kritikája helyett a funkcionális alrendszerek általános kritikájához jutunk. Az elidegenedés, értelemvesztés tapasztalatai - szemben azzal, ahogy Marx feltételezte - nem egyszerűen az értéktöbblet szempontjaihoz kizárólagosan igazodó termelési és csereviszonyok következményei. Továbbá, szemben azzal, ahogy - Weber formális racionalitás fogalma nyomán - Lukács is feltételezte, nem is egyszerúen az absztrakt munkához igazodó tudomány és hétköznapi tudat szintjén egyaránt megjelenő uniformizáló, fragmentált cselekvő perspektíva kifejeződései. Habermas szerint az elidegenedés rendszer és életvilág szétkapcsolódásának, a hétköznapi praxis nyelvi interakciók általi koordinációja helyett, automatizált mechanizmusok révén történő szerveződése nyomán létrejövő tapasztalata. Más szóval egy társadalmi patológiából fakadó élmény: a médiumok expanziója nyomán az önpusztítás lehetőségét magában rejtő gyarmatosítás fenomenológiai leképződése (Habermas 1986: 318).

Az eldologiasodás rendszerek szintjén történő lokalizálásával Habermas egy fontos ponton szakít a kritikai elméletek hagyományával: a pénz médiuma által szervezett gazdasági és a hatalom médiuma által szervezett politikai alrendszereket egyaránt az eldologiasodott társadalmi viszonyok legitim szféráinak tekinti (Weiss 2008: 146). Rendszer és életvilág viszonyát olyan egyensúlyként képzeli el, melyek kölcsönös teljesítmények révén teszik lehetővé egymás működését: a privát szféra munkaerőt és keresletet kínál a gazdasági rendszer számára, az utóbbi jövedelmet és szolgáltatásokat az előbbi számára; a nyilvánosság lojalitást az adminisztratív rendszer számára, az utóbbi pedig szervezeti stabilitást és politikai döntéseket az előbbi számára (Habermas 1986: 320). Minthogy a gazdaság és adminisztratív rendszer területein a hatékonyság és kalkulatív racionalitás logikája adekvátnak tekinthető,

2 Ebben az értelemben az alávetett osztályhelyzetre Lukács kitüntetett episztemológiai pozícióként tekint: minthogy szenvedéstapasztalatok jellemzik, ezért a fennállóval szemben - ha nem is ténylegesen, de potenciálisan kritikai perspektívát implikál. 
a probléma abból fakad, ha innen kitörve, az életvilág szerveződése szempontjából is meghatározóvá válnak. Ebben az esetben a pénz és hatalom médiumai rátelepszenek a kulturális újratermelés, integráció és szocializáció folyamatára, torzítva a kulturális értelmezési mintákat, a társadalmi legitimitást és a személyes identitást.

A rendszerintegráció tágabb kontextusának figyelmen kívül hagyása a Marxot szorosabban követö kritikai elméletek számára egy közös vakfoltot eredményezett. Óhatatlanul rejtve marad számukra a funkcionális differenciálódásban rejlő evolúciós potenciál, ami adott esetben a kapitalizmus válságtendenciáit és patológiáit is képes tompítani. E lehetőség elméleti megragadása nélkül a társadalmi változás egyetlen elképzelhető útja a termelési viszonyok alapjainak átalakítására törekvő forradalom volt. Ennek következtében nem irányult figyelem azokra az empirikus tendenciákra, melyek ezzel éppen ellentétben, a kapitalista termelési viszonyok negatív következményeit igyekeztek csökkenteni. Ezek egyaránt magukba foglalták a társadalombiztosítási rendszer kiépülését és a szociális jogok egyre szélesebb körű kiépülését, fokozatosan elvezetve a jóléti állam modelljéhez (Habermas 1986: 339).

Ennek keretei között az eldologiasodás egyre kevésbé kapcsolódik közvetlenül az értéktöbblet előállításának - osztályhelyzethez köthető - kényszeréhez vagy a formális racionalitásban kifejeződő - osztályhelyzettől független - gondolkodási formákhoz. Ugyanakkor azt sem lehet állítani, hogy megszünne: a gazdasági ingadozásokat kezelni hivatott állami beavatkozásból fakadóan az eredetileg piaci eredetű problémák kihatnak az adminisztratív rendszerre is. Ez utóbbi működését egyre inkább az előbbiben jelentkező válságpotenciálok elhárításának szükséglete határozza meg. Ennek egyaránt következménye a privát hétköznapi élet egyre apróbb részletekbe menő szabályozása (eljogiasodás) ${ }^{3}$ és a demokratikus nyilvánosság által gyakorolt kontroll technokrata logika nevében történő háttérbe szorítása (állampolgári privatizmus, legitimációs válság). Ilyenformán a jóléti állam korántsem mentes az eldologiasodástól: sokkal inkább azt lehet mondani, hogy azt egy összetettebb és ebből fakadóan kevésbé nyilvánvaló konstellációban valósítja meg. Ahelyett, hogy közvetlenül a gazdasági pozíciókban vagy közvetve a gazdasági racionalitásban fejeződne ki, a társadalmi zavarokat kezelni hivatott intézményrendszer müködésének nem szándékolt következményei között fedezhető fel (Habermas 1986: 351-356).

Azáltal, hogy Habermas a társadalmi alrendszerek és a kommunikatív racionalitás feszültségeként értelmezi át az eldologiasodás kérdését, bár kitágítja a kapitalizmus sajátosságaiból kiinduló magyarázó modellt, azonban korántsem hagyja teljességgel maga mögött. Amennyiben az adminisztratív rendszer eljogiasító tendenciáinak expanzióját végső soron a piaci válságok megelőzése motiválja, úgy ha közvetve is, de a rendszergyarmatosítás hátterében továbbra is meghúzódnak a kapitalista termelési viszonyok paradoxonjai. Ezzel a megközelítéssel szakít Honneth, aki a Habermas által megkezdett elmozdulást radikalizálva nem egyszerüen a kapitalizmuskritikát hagyja maga mögött egy rendszerelméleti modellért cserébe, hanem általában a társadalomelméleti kereteket adja fel egy filozófiai antropológiai megközelítésért cserébe. Ennek megfelelően az eldologiasodás értelmezésekor Lukács mel-

3 Ezen a ponton érezhető talán a legvilágosabban, hogy Habermas korántsem csupán kritikailag viszonyult Foucault hatalomelméletéhez. Az eldologiasítás eljogiasító aspektusának bemutatása a foucault-i biohatalom által gyakorolt „kormányzással” állítható párhuzamba. A privát szféra (iskola, család) jogi szabályozása ugyanis kiegészül a terápiás és szociális munkás szakértők felügyeletének kiterjesztésével is. Ezek az érintettek autonóm döntéseit egy tudományos-jogi komplexum kötelező irányelveinek vetik alá, kifejezve az eldologiasító diszkurzív hatalom mikrofizikáját (Habermas 1986: 370-373). 
lett legalább annyira fontos szerzőként támaszkodik olyan eltérő hagyományokba ágyazott szerzőkre, mint Heidegger vagy Dewey. Hasonlóképpen Lukácshoz, ők is azt mutatják be, hogy az a semleges, objektív, formális racionalitáson alapuló viszonyulás a világhoz, ami a modernitásban általánossá vált, korántsem az egyetlen és még csak nem is a legalapvetőbb. Sokkal inkább egy olyan perspektíva, ami a valóság értelmezését beszúkíti, és ennyiben kritikailag értelmezhető (Honneth 2006: 110).

Lukács ebből a szempontból a történelmi materializmus elemzéseire támaszkodik, annak következményeként mutatja be az absztrakt munka megjelenését. Heidegger a filozófia történetéből próbálja kimutatni, miként szorultak fokozatosan háttérbe az egzisztenciális kérdések egyfajta „létfelejtés” során. Ennek hatására a másik perspektívájának figyelembevételén és a tevékenykedésen alapuló „gondoskodás” alapértelmezett perspektívája átadja helyét egy szenvtelen, instrumentális relációnak. Dewey saját elemzéseit nem ágyazza be hasonló történelemfilozófiai keretbe, ehelyett arra törekszik, hogy a hétköznapi cselekvések pragmatikus kereteit mutassa be. Álláspontja szerint a világhoz való viszonyunk alapértelmezésben nem az uralomgyakorlás hierarchikus szerkezetéhez igazodik, hanem egy olyan holisztikus struktúrába ágyazódik, melyben feltárulnak a dolgok egyedi sajátosságai. Azt megelőzően, hogy egy objektiváló perspektívából tekintenénk a világra és egyoldalúan beavatkoznánk müködésébe, igyekszünk egyensúlyi viszonyba kerülni vele, és ehhez interakcióba kell lépünk elemeivel. Minthogy ezekben a helyzetekben nem egy egocentrikus, hanem egy a mások és a dolgok szempontjaira érzékeny, empatikus cselekvőperspektíva figyelhető meg, a világ iránti tiszteletet fejezik ki. Ez a tiszteletadás teremt lehetőséget Honneth szerint arra, hogy a - Lukács és Heidegger által részleteiben kevésbé kidolgozott - torzításoktól mentes, eredeti világhoz való viszonyulás lényegi sajátosságának az „elismerést” tekintse (Honneth 2006: 111).

E belátásból következik, hogy az érzelmileg semleges, objektív megismerési folyamatok kezdőpontjában az eredeti empatikus, az egyedi sajátosságokat tisztelő reláció felfüggesztését találjuk. Ahhoz, hogy az egyén objektív, szenvtelen megismerőként viszonyulhasson a világhoz, a személyek és a dolgok - óhatatlanul morális elköteleződést és szenvedélyt implikáló - elismerését vissza kell vonnia. E távolító gesztust követően alakulnak át a világ elemei partikuláris sajátosságokkal bíró létezőkből absztrakt kategóriák megtestesítőivé. Az eldologiasodás ugyanakkor nem egyszerüen az elismerés hiányaként értelmezhető, hanem sokkal inkább annak „elfelejtéseként”. Ahhoz, hogy a megismerés folyamata beinduljon ugyanis, mindenekelőtt arra van szükség, hogy annak tárgya érdekesként és fontosként tűnjön ki környezetéből. E pillanatoktól elválaszthatatlan az odafordulás gesztusa által implikált elismerési. Az eldologiasodás kulcskérdése ennek megfelelően az, hogy minek a hatására fordul át ez a partikuláris sajátosságokat befogadni képes elismerési perspektíva az univerzális sajátosságokra érzékeny, szenvtelen nézőponttá (Honneth 2006: 124-125).

Lukács az eldologiasodást a kapitalizmus logikája által meghatározott instrumentális racionalizálódás általánossá váló modernizációs tendenciájaként írta le. Ez a felfogás azonban abban az értelemben túlzónak tekinthető, hogy a totálissá váló objektiváló perspektíva egyúttal olyan paradox társadalmi feltételekre is utal, melyek felszámolják az emberi kapcsolatokat és ezáltal a reprodukció feltételeit is. Habermas a kizárólagosságból fakadó paradoxont úgy próbálja elkerülni, hogy rendszerek formájában azonosít olyan szférákat, ahol normatíve legitimnek tekinthető az eldologiasítás, és a rendszerek illegitim határátlépéseként mutatja be az elismerés felejtését. Ez a felfogás abban az értelemben problematikus, 
hogy a funkcionális szükségletek önmagukban aligha szolgálhatnak normatív igazolásként (Honneth 2006: 126-127). Ilyenformán az eldologiasodást akár a modernizációtól elválaszthatatlan szükségszerü tendenciaként (Lukács), akár egy folyamatának túlkapásaként (Habermas) magyarázzuk, óhatatlanul paradoxonokhoz lyukadunk ki. További nehézség, hogy sem Lukács, sem Habermas segítségével nem tudunk válaszolni arra a kérdésre, hogy fenomenológiai szinten miként történik maga az elismerés feledése: utaljunk bár a piacra vagy a rendszerekre, mindkét esetben meg kellene tudni mutatni, hogy e strukturális szint hatásait milyen mechanizmusok közvetítik a cselekvők felé.

Mindebből Honneth szerint az következik, hogy le kell mondani arról az igényröl, hogy az eldologiasodást általános társadalomelméleti keretben értelmezzük. Ehelyett olyan univerzális antropológiai modellt keres, amiben a társadalmi kontextus elismerésfeledésre gyakorolt hatásai általánosságban ragadhatók meg. Ehhez mindenekelőtt a feledés mibenlétét kell tisztázni: az nem valamilyen tudatosult ismeret eltűnéseként fogható fel, hanem sokkal inkább egy diszpozíció háttérbe szorulásaként. Az eldologiasodás az empátián alapuló eredeti viszonyulásnak az elhomályosulásaként írható le: ahogy az érdekesként felbukkanó partikuláris dolgot elkezdjük kiismerni, fokozatosan természetessé válik számunkra, aminek következtében fokozatosan beolvad a háttérbe. Önmagában ettől még nem tekintünk rá absztrakt tárgyként, azonban a figyelem fókuszából való kikerülés előkészíti az eldologiasító percepció számára a terepet. Mindenekelőtt azáltal, hogy az életvilág evidens tartományába bekerülő értelmezéseink olyan sémaként kezdenek müködni, melyek felülvizsgálatára csak indokolt esetben kerítünk sort. A sematizálódás abban az esetben válik ténylegesen eldologiasodássá, ha felbukkan egy fontos cselekvési cél, és a környezet elemei felhasználható eröforrásokként mutatkoznak meg a cselekvő számára. Ebben az értelemben az eldologiasodás a világhoz való viszonyulás temporális szerkezetének hiányzó transzparenciájára vezethető vissza: abból fakad, hogy az életvilág horizontján újabb és újabb jelenségek bukkannak fel, folyamatosan háttérbe szorítva a korábbi tapasztalatokat, valamint saját szempontjaikhoz igazítva azokat (Honneth 2006: 130-131). ${ }^{4}$

Egy ilyen értelemben vett eldologiasodás egyszerre vonatkozhat a természetre, a másikra és önmagunkra. ${ }^{5}$ Ezeken a szinteken egyaránt megfigyelhető, hogy egy alapértelmezett elismerési reláció a megszokás révén elhalványulva közönnyé válik, hogy végül átadja helyét egy eltárgyiasító relációnak. Honneth korábbi munkái alapján ugyanakkor az is nyilvánvaló, hogy az elismerés feledéseként felfogott eldologiasodásnak közvetlen társadalomelméleti következményei vannak. A szeretet, szolidaritás és jogi elismerés fogalmai révén válik érthetővé, hogy milyen értelemben rejlik kritikai potenciál az eldologiasodás fogalmában: ezek elhalványulni hagyása, vagyis feledése, önbizalmától, önbecsülésétől és méltóságától fosztja meg az egyént, vagyis végső soron emberi mivoltát lehetetleníti el (Honneth 2013). Az eldologiasítás fogalmának elismeréselmélethez való hozzákapcsolása egyúttal azt is jelenti, hogy

4 Az eldologiasodás elismerésfeledésként való megragadásával Honneth hasonló paradox, önpusztító tendenciára kíván rámutatni, mint Habermas a gyarmatosítástézissel. Minthogy az elismerés nélkülözhetetlen az elemi megismerési folyamatokhoz, így annak a szisztematikus megismerés nevében történő háttérbe szorulása magát az eredeti célt lehetetleníti el (Geuss 2008).

5 Az öneldologiasítás kérdésének az eredeti tanulmány továbbírt változatában Honneth kiemelt szerepet szán, rámutatva, hogy a modernitásban egyre több helyzetben kényszerül önmagát tárgyként megkonstruálni az egyén: a munka világában az életrajzok, a párkapcsolatok esetében a párkeresői profilok tekinthetők megvilágító példáknak (Honneth 2008: 63). 
Honneth lemond egy olyan általános társadalomelmélet igényéről, amely a kordiagnózis igényével lép fel. Ehelyett empirikus kérdésként tekint az eldologiasodásra, ami tetszőleges társadalmi konstelláció patologikus formájaként bukkanhat fel, anélkül ugyanakkor, hogy ezt - akár a kapitalista termelési viszonyok, akár a rendszerdifferenciálódás formáját öltő általános integrációs sajátosságok meghatároznák. ${ }^{6}$

Marx, Lukács, Habermas és Honneth koncepcióinak áttekintése után az eldologiasodás összetett modellje vázolható fel. A mások általi objektiválás tapasztalata egyrészt táplálkozhat a termelési viszonyok strukturális és technikai sajátosságaiból, vagyis egy alávetett és kiszolgáltatott osztálypozícióból. Ebben az esetben a társadalmi szenvedés elsősorban a testi fájdalom, éhezés, nélkülözés és fizikai kiszolgáltatottság formáját ölti. Másrészt fakadhat a hétköznapi életet átható - a tudományos világképben és bürokratikus legitimitásban egyaránt kifejeződő - formális racionalitás logikájának totálissá válásából. Ebben az esetben a társadalmi szenvedés az értelemproblematika formájában mutatkozik meg, egy értelemvesztett, teodíceára képtelen élet formájában. Harmadrészt előállhat a funkcionális szempontokat kifejező, szimbolikusan általánosított kommunikációs médiumok által szervezett társadalmi szférák expanziójának köszönhetően. Ebben az esetben a társadalmi szenvedés a személyközi kommunikáció beszükülésében fejeződik ki, a másik iránt közönyös, közös világot teremteni képtelen kapcsolatok formájában. És végül - egyfajta antropológiai sajátosságként - eredhet a másikhoz és a világ dolgaihoz való viszonyulást elemi szinten átható elismerés feledéséből. Ebben az esetben a társadalmi szenvedés a másikhoz és a dolgokhoz való viszonyulás elidegenedett mivoltában érhető tetten, egy kölcsönös megértésre és gyönyörködésre egyaránt képtelen perspektíva formájában.

A késő modernitásban ilyenformán az eldologiasodás tapasztalata egy összetett lehetőségtérbe ágyazódik: noha a kapitalista termelési viszonyokkal való közvetlen (osztályhelyzet) és közvetett (formális racionalitás) kapcsolata továbbra is meghatározó, amellett legalább olyan fontos az arra nem redukálható funkcionális differenciálódás, valamint a világhoz való partikuláris viszonyulás eltünésének potenciálja is. Ennek megfelelően egyrészt elképzelhetők olyan társulások, vagy éppen élethelyzetek, melyeket a társadalmi szenvedés egyik vagy másik dimenziója jellemez, azonban a többi dimenzió mentén szerveződő komplementer kapcsolódás ellensúlyozza azok hatását. Másrészt olyanok is, melyekben az eldologiasodás totálissá válik abban az értelemben, hogy az alávetett osztálypozíció, a bürokratikus legitimáció, a rendszerszerű kommunikáció, valamint a sematikus cselekvőperspektíva koherens egészet alkot, a materiális nélkülözés, az értelemvesztés, a kommunikációképtelenség és az elismeréshiány együttes tapasztalatát eredményezve. A társadalmi szenvedés e mintázatainak feltérképezése döntő fontosságú a kritikai elméletek számára, amennyiben kijelölik azokat a kihívásokat, melyek a késő modern cselekvő mozgásterét szervezik.

6 Honneth e megoldása felemásnak tekinthető abban az értelemben, hogy bár minden korábbi kísérletnél részletesebben ragadja meg az eldologiasodás univerzális fenomenológiai sajátosságait, végső soron lemond arról, hogy ezt hozzákapcsolja a társadalomelméleti fogalmakhoz. Ennek megfelelően nem meglepő az sem, hogy több kommentátor is felemás érzésekkel fogadta megoldását (Lear 2008; Weiss 2008). 


\section{Az eldologiasodás késő modern komponensei}

Az elméleti keretek tisztázását követően rátérhetünk empirikus alkalmazásukra. Az alábbi szakaszban azt a kérdést vizsgálom meg, hogy az eldologiasodás fentiekben bemutatott, különböző korszakokban született modelljei miként hasznosíthatók a késő modern társadalmi szenvedés értelmezése során. E célból egy narratív életútinterjút használok fel, ami információgazdagsága és kötetlensége révén lehetőséget kínál e sokféle típus megragadására. Természetesen egy ilyenfajta elemzésnek megvannak a maga korlátai. Mindenekelőtt az egyéni élettörténet fókuszba állításával csupán az egyéni perspektíva tanulmányozására nyílik lehetőség, ami óhatatlanul ahhoz vezet, hogy a releváns társas viszonyok egy torzóját adja ki. Másrészt az interjúk, legyenek bármennyire is függetlenek előzetes konceptuális megfontolásoktól, mégis egy szubjektív lenyomatnak tekinthetők. Ebben az értelemben általuk nem egyszerüen egy torzóhoz, hanem a hálózatok egy egyén identitáskonstrukciójának szürője által szelektált szeletéhez nyílik hozzáférés. Ezt szem előtt tartva belátható, hogy a narratív interjúk alapján hozzávetőleges kép alkotható: e módszertani keretben csupán egy egyén élettörténetének az identitás szempontjából kiemelt jelentőségü szakaszát meghatározó kapcsolódások rekonstrukciójára nyílik lehetőség.

Azonban nyilvánvaló korlátai ellenére sem mondható, hogy ez csekély lehetőség lenne. Ahogy az White hálózatelméletéből is kiderül (2008), a társas kapcsolódások nyomot hagynak az identitáson, ebben az értelemben megalapozottnak tekinthető egy az identitáskonstrukcióból kiinduló módszert a társas viszonyok rekonstrukciójához felhasználni. Önmagában az, hogy a társas relációk hálózatának egy külsődleges megfigyelő által létrehozott listája helyett egy szubjektív szelekció alapján létrejött lista áll rendelkezésünkre, nem tekinthető kizáró oknak: bizonyos értelemben az eldologiasodást kifejező társadalmi szenvedés feltérképezéséhez a cselekvőnél nincs is autentikusabb forrás. Természetesen egy ilyen rekonstrukcióhoz a narratív interjúkban megjelenő explicit információk mellett azoknak az - adott esetben az elbeszélő számára sem hozzáférhető - rejtett összefüggéseknek a feltárására is szükség van, melyek hálózati behatások lenyomataiként értelmezhetők. E célból az elemzés sajátos módszerére van szükség.

Míg az életútinterjúk narratív elemzése az identitás konstrukciójának hermeneutikai szempontjaihoz igazodik, az alábbiakban alkalmazott kapcsolati rekonstrukció az egyes élethelyzetekben hatást gyakorló társak és dinamikák azonosítására szolgál. E célból az életútinterjúkban megjelenő explicit és implicit információkat első körben aszerint osztályoztam, hogy felbukkan-e bennük az eldologiasodás osztályhelyzettel, racionalizálódással, rendszergyarmatosítással vagy elismerésmegvonással összefüggő formája. A felbukkanó típusok e nyers adatbázisát második körben az egyes életszakaszokhoz rendeltem hozzá. Ezáltal lehetőség nyílt a különböző időszakokon belül feltérképezni az eldologiasodás különböző formáit, valamint azokat az esetleges kompenzatorikus viszonyokat, melyek a belölük fakadó szenvedést ellensúlyozni tudták. ${ }^{7}$ Ezen elökészítést követően tértem rá az eldologiasodási

7 A felhasznált interjú a „20. század hangja” archívumból származik a Kovács Éva által vezetett „A Kádár-korszak társadalmi emlékezete” címủ kutatásából, rögzítésére 2005-ben került sor (a kutatás tágabb bemutatásához lásd: Kovács 2008). Az elemzésben nagy segítségemre volt Takács Flóra és Bacsák Dániel, akikkel összesen 17 interjút vizsgáltunk meg, részben e tanulmány szempontjai szerint. A bemutatott esettanulmány ezek közül került kiválasztásra. 
mintázatok rekonstrukciójára, megvizsgálva, hogy az egyes életszakaszokban milyen kevert típusok voltak jellemzőek és azok milyen dinamikákat eredményeztek.

Lajos gyermekkorának meghatározó élménye a család szegénysége: ez negatív referenciapont lesz, amit mindenáron el akar kerülni. E tapasztalatok nem csupán fiatalkori döntéseit befolyásolják, hanem életre szóló ösztönzést adnak egy szigorú munkaetika formájában: „Az volt a baj, ha valaki nem dolgozott, azt én is megvetettem, merthogy dolgozni kell." Ennek megfelelően korán munkába áll: az elsősorban gazdasági kiszolgáltatottsággal azonosított családból a gazdasági önállóságot jelentő és megbecsültséget kifejező munka világába menekül. Ezt a folyamatot különösen felerősíti, hogy a családi intimitást korlátozza a nélkülözés. Anyja önfeláldozóan dolgozik, azonban az empátiának nincs tere, a szenvedésekről nem szabad beszélni sem: „...az édesanyám (...) cséplőgépnél, aztán a csirkegyárba dolgozott, hát, amikor tudott, aztán meg a téeszbe. De hát aztán az se nagyon ment, mer hát, nem nagyon bírta ő már azt, egyszóval nem neki való volt az, nehéz munka volt, na, mindegy". Édesapja elhagyja a családot, nevelőapját nem szereti, és nem is becsüli, amiért nincs se anyagi, se kulturális tőkéje. Az ő halála után legnagyobb gyerekként hamar felnőtté kell válnia, ami egyaránt megnyilvánul saját fogyasztása korlátozásában és a testvérei nevelésébe való besegítésben:

Tizennégy éves voltam, mikor meghalt a mostohaapám. Na, most akkor öcsém az hárommal, a másik meg öt évvel fiatalabb, mint én. Hát szóval még kicsik voltak, magyarul. Hát azért egyedül. Aztán meg én is segítettem, hogy így mondjam, nevelni őket, mer én is elmentem dolgozni, azt nem sok pénz volt, nem sok pénz, de azé, azé az is valami.

Tizenöt éves korában dolgozni kezd a vasútnál, a munka az identitása alapja lesz (nem vesz ki szünnapot 30 évig). Noha az első munkája kemény, fizikai jellegü, viszont szolidárisak vele: „Megmondom őszintén, nekem tetszett, mert hát mindjárt úgy alakult a dolog, hogy hát nem úgy kezeltek, mint egy, hogy mondjam, egy felnött dolgozót (...), könnyebb dolgokat csináltam végül is." Továbbá lehetőséget kínálnak neki, hogy anyagbeszerzőként próbálja ki magát, amiben sikeres lesz. Főnöke megbízik benne, ő pedig ügyesen eligazodik a kádári különalkuk és kiskapuk világában:

A főnök, aszongya, hogy téged küldelek én Pestre. Jobban járok én, mint a Ferivel, az mindig részeg, sosincs semmi anyag. (...) én mindjárt elsőre csináltam egy vagon árut haza. Aszongya, érdekes, aszongya, Ferit háromszor küldtem el, nem bírta beszerezni, te meg egyből elsőre. Hát mondom, volt, csak oda kell menni, én bementem a raktárba, bebújtam a pult alatt, aztán mentem befele. Hát fiatal srác voltam, hát hogy a fenébe, tizenhat évesen, hát, de szemtelen is voltam, rámenős.

Bár cselekvési szabadsága is van és összességében elégedett, amikor úgy érzi, hogy kevés a pénz, továbbáll, előbb raktárosnak, majd fütőnek. Életét meghatározza, hogy a rendszer materiális értelemben megbízható, kiszámítható.

Összességében Lajos fiatalkorát egy kettősség jellemzi. Otthon abban az értelemben eldologiasodott viszonyok vannak túlsúlyban, hogy családtagjai egymáshoz való viszonyát egy sajátos elismeréshiány jellemzi. Minthogy apja elhagyja őket, anyjához túlterheltsége okán nem tud kapcsolódni, nevelőapjával idegenek maradnak egymás számára, testvéreiről pedig kénytelen anyagilag gondoskodni, így otthon nincsenek olyan kötések, melyek nem valamilyen sematikus keretben szerveződnek. Az apa az áruló, az anya a mártír, a nevelőapa a mostoha, a testvérei a feladat szerepében adottak számára, ellehetetlenítve annak a lehetőségét, 
hogy egyediségükben kapcsolódjon hozzájuk. Az eldologiasodás ezen intimitásbeli formáját kiegészíti továbbá egy osztályalapú is: a létszükségletek kielégítéséért folytatott küzdelem arra kényszeríti őket, hogy áruvá tegyék munkaerejüket, és ennek perspektívájából viszonyuljanak a világhoz. Szemben a családon belüli elismeréshiánnyal, ez az osztályalapú sajátos módon korántsem csupán szenvedéssel jár. Egyrészt anyagi biztonságot teremt, másrészt lehetőséget az önbecsülésre. Vagyis annak ellenére, hogy maga a rendszer közönyösen viszonyul Lajos egyéni szenvedéstapasztalataihoz, mégis felkínál egy olyan világos, kiszámítható keretet, amin belül biztosítottnak látja boldogulását, és sorsa aktív alakítójává válhat. Ebben az értelemben a munka világa legalább saját eldologiasító logikája mellett egyúttal emancipatorikus is: egy olyan életút lehetőségére utal, ami a feltételeihez alkalmazkodók számára hosszú távon is megoldást kínál a materiális szükségletkielégítés kihívásaira.

A munkába állást követően Lajos hamarosan maga mögött hagyja a számára egyre inkább ballaszttá váló otthonát, különköltözik, és önálló életet kezd. Ekkor elsősorban karrierútja köti le minden figyelmét, ahogy egyre nagyobb biztonsággal mozog a kiismert államszocializmus keretei között. Nagy állami szállítási vállalatoknál dolgozik, ugyanakkor nem kötődik egyikhez sem, ahol aktuálisan a legkedvezőbbek a munkafeltételek, ott marad, majd jobb ajánlat esetén továbbáll:

Volt egy iskolatársam, aki mozdonyfütőként kezdte, és mozdonyvezető lett. Már akkor mozdonyvezető volt. Hát, mondom, megpróbálom én, hátha nekem is sikerül. De hát aztán nem sikerült, mert én nem is akartam, nem, ahhoz nem volt kedvem. Aztán jobban izékhöz, jobban, végül is az autók felé húzott, úgy gondoltam, hogy énnekem az jobban tetszett, és bejött ez a lehetőség, kihasználtam.

Minthogy sem érdemi előrelépésre, sem pedig munkaerőpiaci deprivációra nincs esélye, ezért szenvtelenül végzi munkáját, igyekezve kiélvezni a benne rejlö lehetőségeket és keresetét eközben kiegészítve mellékállással. A Kádár-rendszer viszonyait ebben az értelemben belakja. Alapélménye, hogy diszfunkcionális ugyan a rendszer, amitől környezetével együtt függ, de nem zavarja különösebben, mert kapcsolatai és a teljes körü foglalkoztatás biztonságot és szabadságot teremt számára:

Mindig én jöttem Pestre, és mindig én voltam az anyagbeszerző, hogy így mondjam. És ez többre ment mindennél, mert anyaghiány volt állandó jelleggel. (...) Utaztam is, meg elintéztem a délelőtt a dolgomat, én utána mentem a vidámparkba, az állatparkba, külön kertbe, vagy ahova akartam, úgyhogy jó volt. Tetszett nekem.

Miközben a munka világában kiteljesedik, saját családot is alapít, három gyereke születik. Nősülése utána nem tartja a kapcsolatot eredeti családjával. Feleségével való viszonya instrumentális, fiait keményen neveli, igyekszik átadni nekik a munkaethoszt. Fő életcélja a gyerekek materiális létfeltételeinek biztosítása, eközben érzelmileg kevéssé tud kapcsolódni hozzájuk. Egyetlen közös pont a foci, amit szintén az legitimál, hogy értelmes és hasznos tevékenység:

Én szerettem a gyerekeket, még most is szeretem őket, most nem erről van szó, de hát imádtam, futballoztam velük (...) gyerekeimmel futballozok, hát mondom, foglalkozok velük legalább. Hát mondom. nem otthon nyomkodják a, a játékot, meg mit tudom én mi, csavarognak akárhol, meg szipóznak, meg cigiznek, mondom, ott vannak velem, és látom, mit csinálnak. Nem? 
Legnagyobb gyereke betegeskedik a rossz lakásviszonyok miatt, ezért saját lakás építésébe kezdenek, ahova elköltöznek. A betegség azonban rányomja a feleségével való viszonyra is a bélyegét, csalódik felesége funkcionális képességeiben, majd elválik:

Nem bírta a pénzt beosztani, olyan volt, hogy jó, odaadtam neki nyolcvanezer forintot, mikor disznóval foglalkozott, és akkor egy hét múlva se pénz, semmi, semmi, semmi, szóval, se ruha a gyerekeknek, semmi. Én közbe Pesten tizenöt napot dolgoztam. Hazamegyek, nincs semmi. Hát hogy van ez. És akkor még neki állt följebb. Hát aztán mondom, ezt, izé, nem.

Összességében Lajos felnőttkorának első szakaszát hasonló kettősség jellemzi, mint a gyermekkorát, miközben a szereplők kicserélődnek és a hangsúlyok áthelyeződnek. Osztályhelyzetéből fakadó kiszolgáltatottsága megszűnik: minthogy szigorú munkaetikája és meritokratikus szemlélete, kiegészülve a kádári hibrid társadalmi viszonyok kiismerésével, sikeressé teszik, így önbecsülésre tesz szert és a számára legfontosabb materiális biztonságot megteremtheti (ezzel valósítva meg gyerekkorába visszanyúló identitásprojektjét). Ugyanakkor a munka funkcionális racionalitáson alapuló világa áthatja élete egészét. A családi kapcsolatokat szintén materiális szinten müködteti: nemi munkamegosztást érvényesít, feleségétől magáéhoz hasonló hatékonyságot vár el, gyerekeinek a munkaethoszt szeretné továbbadni. Ebben az értelemben a funkcionalitás szempontjai a munka világán túl is érvényesülnek: a gyereknevelésben és a feleségéhez való viszonyban is meghatározóvá válva, kifejezik az életvilágot gyarmatosító hatást. Azonban ez végül problémákhoz vezet: a közös ügyek, konfliktusok megvitatására nincs mód, és ezért a pusztán instrumentális alapokon nyugvó, eldologiasodott családi egység végül felbomlik. Ebben az értelemben az eldologiasodott és komplementer cselekvési terek bár továbbra is egyensúlyban vannak, dinamikájuk mégis épp ellentétes a fiatalkorához képest. Ebben az életszakaszban már megmutatkoznak Lajos számára az eldologiasodott családi viszonyokból fakadó korlátok. Miközben a munka világában nem akadályoz a sematikusság egy stabil, kiszámítható mobilitást, azonban a családban már ellehetetleníti az olyan felmerülő problémákkal való megküzdést, mint amilyen a gyerek betegeskedése. Minthogy az eldologiasodott intimitás alternatívája nem hozzáférhető Lajos számára, így végül a kezeletlen házastársi konfliktusok elmérgesednek és váláshoz vezetnek, előrevetítve egy negatív dinamika lehetőségét.

Miután elválik feleségétől, alapvetően megvan egyedül. A szállítmányozással foglalkozó munkájában töretlenül kielégülést talál, minthogy vállalatánál nagy tisztelet és széles kollegiális kapcsolatháló övezi. Kivételeznek vele, elismert szakértőként kezelik, akinek lehetősége van kiállni saját igazáért. Mindezek ellenére a munkával járó stressz és terhelés hosszú távon megviseli. Bár munkásszállóra költözik, ezt önmagában nem tekinti problémának, inkább vágyait igazítja a realitásokhoz. Új barátnője lesz, azonban vele sem túl intenzív az érzelmi élete. Válás után nem sokkal a gyerekek hozzászöknek és szakítanak anyjukkal. Kapcsolatai segítségével szerez szállást és munkát a gyerekeknek:

Egy év múlva, mikor elváltunk, a gyerekek elszöktek tőle, Pestre hozzám, én ott laktam szállón, egyszer csak jön a két gyerek, hogy apu, mi nem megyünk vissza többet, anyutól eljöttünk, csinálj valamit, szóval legyen munkahelyünk, meg hogy hol aludni. Hm, mondom, ez nem semmi, hát azért gond volt ám egy pillanatra (...) Ugye, kész tények elé állítottak, hát tizenhat éves volt az egyik fiam, a másik épp nagykorú. Na, mindegy. És akkor hát, hát valahogy megoldottam, mert a barátnőm fönöke pikk-pakkra megírta az akármilyen papírt, mentem, intéztem a srácok sorsát, és már este szállójuk is volt, munkahelyük is volt. 
Ezt követően igazolva látja egész puritán-meritokratikus habitusát: nem csak sikerült átadnia nekik a munkaethoszt, de ő jelenti számukra a biztonságot (azt, amit az apja neki nem tudott megadni). Elsősorban materiális szinten segít nekik egy a sajátjához hasonló életforma berendezésében (munkásszálló és kiszámítható munka).

Összességében a válást követő években sajátos kettősség jellemzi Lajos helyzetét: egyrészt a család felbomlásával strukturális szempontból deklasszálódik, ugyanakkor ez a kitettség rejtve marad számára. Mivel megszokta a paternalista rendszerek eldologiasodott biztonságát, továbbá azon belül elért érdemei alapján a státusza fenntartásában bízhat, ezért az osztályalapú eldologiasodás megújuló veszélye látens formában jelenik meg csupán. Továbbá, bár az eldologiasodás osztály- és rendszeralapú formái egyaránt detektálhatók életében, a belőlük fakadó szenvedéspotenciál aktualizálódását megakadályozza a családi viszonyok szintjén lezajló változás. Ahogy gyerekei hozzá költöznek, és egyedül lesz kénytelen gondoskodni róluk, új, immáron kevésbé eldologiasodott intim szerepbe kerül - életében elöször. Ennek jelentőségét árnyalja ugyanakkor, hogy a számára legfontosabb materiális viszonyok szintjén összességében a válással mégis bizonytalanabb lett pozíciója: ebben a helyzetben az esetlegesen felmerülö újabb kockázatok kezelésének esélye lecsökken.

A rendszerváltás pontosan ezt a veszélypotenciált élezi ki. Lajos strukturális pozíciója drasztikusan megváltozik, amennyiben nincs többé lehetősége a korlátozott, de kiszámítható materiális biztonságra. A munkásszálló megszünik, és - a megszokott magabiztossággal otthagyott - munkahelye helyett ezúttal nem talál új állást:

Hú, hát úgy alakult, kérem szépen, hogy hát ugye a lakáshelyzet az, hogy megszűntek ezek a szállódolgok, hát én, hogy mondjam, más lett a főnök. Jött egy másik, azt ismertem már régről, már nem jöttünk ki egymással egyáltalán, aztán még hozta a haverját, akit még jobban utáltam, azt még jobban, régebben ismertem, és gazembernek mindig, na akkor mondom ezeknél nem dolgozok, fölmondtam. Utána nem kaptam munkahelyet, mer mondom, negyvenöt éven túl már nem megy. Na aztán ugye nem kaptam, hát így aztán nem ..., se nyugdíj, se semmi, hát alkalmi munkákból éltem, eljártam utcaseprőnek, nem röstellem, eljártam egy évig, utcaseprő voltam. Csináltam.

Hirtelen a korábbi jól ismert paternalista rendszer helyett egy kiszámíthatatlan, kizsákmányoló piaci mezőben találja magát, ahol túl öregnek számít. Próbál alkalmazkodni továbbra is (pl. utcaseprést vállal, megelégszik a hajléktalanszállóval), és gyerekkorából meglévő puritán habitusa is protektív tényezővé válik (vágyait a lehetőségekhez igazítja). Azonban öszszességében mégis kilátástalan helyzete kerül: betegségek támadják meg, ami ellehetetleníti a munkakeresést, így egyetlen bevételi forrása a korkedvezményes nyugdíj marad. Családibaráti kapcsolatai beszűkülnek: minthogy gyerekeit felnevelte, így már nincs igazán dolga velük. Ugyanakkor nem lázad a sorsa ellen, úgy érzi, elérte célját, a maradék időt pedig kitölti a fennálló keretek között: így csalódottságát a korábbi sikerekből fakadó jóérzés (ki tudott törni a családi sorsból és gyerekeit felnevelte) valamelyest ellensúlyozza.

Összességében a rendszerváltás utáni időszakban az eldologiasodás az államszocializmusban direkt formában nem látott, osztályhelyzetből fakadó formája kerül előtérbe. Míg az államszocializmus eldologiasító, ám egyúttal szolidaritást is biztosító intézményrendszerére többé-kevésbé egész felnőttkorában olyan biztosítékként számíthatott, ami a nehézségek esetén - ugyan uniformizáló, ám mégis megbízható - segítséget kínált fel, addig a rendszerváltással az eldologiasodásból fakadó következmények dominássá váltak. Ahogy elvesztette lakhatását, a kiszámíthatatlanná vált munkaerőpiacon pedig nem sikerült tudását 
a szükséges áron értékesítenie, vagyis bérmunkára alkalmatlanná vált, úgy nem csupán magára maradt, hanem egyúttal „felesleges” lett. Ebben az értelemben strukturális szempontból megszünt szubjektumként létezni, a szenvedései láthatatlanná és irrelevánssá váltak a társadalmi dinamikák számára. Minthogy családjára vagy közösségi kapcsolatokra szintén nem támaszkodhatott, funkcionálisan a munkaerőpiac számára értéktelenné vált, egyéb stratégiák pedig nem voltak hozzáférhetők számára, elfogytak az alternatívái: az eldologiasodás tapasztalata meghatározóvá vált számára.

Végigtekintve Lajos életútján, jól látható, hogy a különböző forrásból fakadó eldologiasodás milyen sokféle fenomenológiai mintázata képzelhető el. A gyermekkort meghatározó osztályalapú eldologiasodásra a családi viszonyok elismeréshiánya épült rá. Az ebből fakadó szenvedésre Lajos az osztályhelyzet megváltoztatására tett kísérlettel reagált. Minthogy a korai munkába állás sikeresnek bizonyult, így ez egyúttal olyan receptté is vált számára, ami mellett a későbbiekben is kitartott. Bár az államszocialista keretek között többé nem kellett a materiális kiszolgáltatottságtól tartania, az eldologiasodás funkcionalista formája korántsem volt ismeretlen számára. Ez azonban totálissá - azzal összefüggésben, hogy maguk az államszocialista alrendszerek is a különalkuk logikájával egészítették ki a szimbolikusan általánosított médiumokét (Sik 2010) - soha nem vált. Így annak ellenére, hogy immár saját családján belüli viszonyait is - a szeretet elismerésmegvonásának formáját öltő - eldologiasodás jellemezte, összességében ebben az időszakban megvoltak az autonómia és szabadság terei. Ezt a képletet előbb válása rajzolta át, aminek következtében egyfelől materiális biztonsága megroppant (munkásszállóra költözik), másfelől új emancipatorikus szerepek találták meg (gyerekei hozzá fordulnak). Ennek hatására egyelőre csak látens módon bár, de osztályhelyzete szempontjából eldologiasodásnak lesz kitéve, miközben az intim kapcsolatok szintjén csökken eldologiasodása. Később a rendszerváltás drasztikus változásokat eredményez: ahogy elveszti munkáját, munkaképességét és az utcára kerül, továbbá gyerekei is függetlenednek tőle, kiszolgáltatottság jellemzi életét. Ennek következtében a „feleslegesek” dehumanizát státuszából fakadó társadalmi szenvedés válik meghatározó tapasztalatává.

\section{Záró megjegyzések}

Az eldologiasodás Marxtól Honnethig tartó történetére úgy tekinthetünk, mint a modernitás egy meghatározó patológiáját egyre általánosabb társadalomelméleti keretben magyarázó modellek sorozatára. Ezekben közös, hogy a társas viszonyok különböző konstellációira utalnak, melyek a világhoz és a másikhoz való viszony episztemológiai szerkezetét oly módon alakítják át, hogy annak morális tartalma kiüresedik. Annak ellenére, hogy az eldologiasodást a kritikai elméletek egymást követő generációi a társadalmi cselekvések egyre szélesebb körére értelmezték, törekvésük mindaddig korlátozottan lehet sikeres, míg az elméletek a társadalmi integráció szintjén beszúkített modellel dolgoznak. Ahhoz, hogy az eldologiasodást a modern társadalmak univerzális patologikus potenciáljaként értelmezhessük újra, önmagában sem a történelmi materializmus, sem az instrumentális racionalizálódás, sem a rendszerdifferenciálódás, sem pedig az elismerés társadalomelméleti keretei nem elégségesek. Ehelyett a társulások olyan átfogó modelljére kell támaszkodnunk, amely mindezeket képes magába integrálni. 
A fenti esettanulmány egy ilyen megközelítést igyekezett illusztrálni. E példa segítségével bemutatható volt, hogy a különböző modernizációs szakaszok egymásra rétegződésével jellemezhető konstellációban soha nem kizárólag a kapitalizmus vagy a formális racionalitás vagy a funkcionális differenciálódás vagy éppen a világhoz való sematizáló reláció tekinthető a kritika tárgyának. Sokkal inkább ezek valamely kombinációja, ami ráadásul az eldologiasodás különböző dimenzióinak kölcsönhatásában is formálódik. Az eldologiasodás különböző forrásból származó dimenzióinak szétszálazása egyrészt további teoretikus kutatások számára nyit utat, amennyiben felveti az azok egymást erősítő vagy éppen ellensúlyozó kölcsönhatásaira vonatkozó kérdést. Másrészt a praxis számára is kitüntetett jelentőségü: hatékony társadalompolitikai válaszok ugyanis csakis oly módon képzelhetők el, ha az egyik vagy másik társadalomelméleti modellre történő redukcionizmus valamely formája helyett átfogó szemléleti kerettel közelítünk a társadalmi szenvedés határállapotaihoz.

\section{Hivatkozott irodalom}

Arato, Andrew (1972): Lukacs' Theory of Reification. Telos 11(1): 25-66. DOI: https://doi.org/10.3817/0372011025.

Geuss, Raymond (2008): Philosophical Anrophology and Social Criticism. In Reification - A New Look at an Old Idea. Martin Jay (szerk.). New York: Oxford University Press, 120-131.

Habermas, Jürgen (1986): Theory of Communicative Action. (2. kötet.) Boston: Beacon Press.

Honneth, Axel (2006): Reification. A Recognition-Theoretical View. The Tanner Lectures on Human Values. Interneten: http://tannerlectures.utah.edu/_documents/a-to-z/h/Honneth_2006.pdf (letöltve: 2017. július 06.).

Honneth, Axel (2008): Reification and Recognition. A New Look at An Old Idea. In Reification. A New Look at an Old Idea. Martin Jay (szerk.). New York: Oxford University Press, 17-97.

Honneth, Axel (2013): Harc az elismerésért. Budapest: L'Harmattan.

Kovács Éva (szerk.) (2008): Tükörszilánkok. Kádár-korszakok a személyes emlékezetben. Budapest: MTA SZKI 1956-os Intézet.

Lear, Jonathan (2008): The Slippery Middle. In Reification A New Look at an Old Idea. Martin Jay (szerk.). New York: Oxford University Press, 131-147.

Lévinas, Emannuel (1988): Useless Suffering. In The Provocation of Levinas. Rethinking the Other. Robert Bernasconi és David Wood (szerk.). London: Routledge, 156-168.

Lukács György (1971): Történelem és osztálytudat. Budapest: Magvető.

Márkus, György (1982): Alienation and Reification in Marx and Lukacs. Thesis Eleven 5(1): 139-161. DOI: https:// doi.org/10.1177/072551368200500111.

Marx, Karl (1955): A tőke. Első kötet. Budapest: Szikra.

Sik Domonkos (2010): A cselekvéskoordináció szerkezetváltása? Szociológiai Szemle 20(1): 74-111. Interneten: http://www.szociologia.hu/dynamic/szocszemle_2010_1_74_111_sikd.pdf.

Sik Domonkos (2015): A modernitás rétegei. Budapest: ELTE Eötvös Kiadó.

Weiss János (2008): Az eldologiasodás elismeréselméleti értelmezése. Fordulat (1): 145-150. Interneten: http://fordulat.net/pdf/1/weiss.pdf.

White, Harrison C. (2008): Identity and Control. How Social Formations Emerge. Princeton, NJ: Princeton University Press. DOI: https://doi.org/10.1515/9781400845903. (Magyarul részlet: Identitás és kontroll. 1. fejezet: Az identitások kontrollt keresnek. Replika (75): 43-63. Interneten: http://replika.hu/replika/75-03.)

Wilkinson, Ian (2005): Suffering. A sociological introduction. London: Polity. 
96 replika 